\title{
Responding to new severe diseases - the case for routine hospital surveillance and clinical networks in Europe
}

G Thomson (Gail.Thomson@hpa.org.uk) ${ }^{1,2}$, A Nicoll3

1. Health Protection Agency (HPA), Porton, United Kingdom

2. Intensive Care Society, London, United Kingdom

3. European Centre for Disease Prevention and Control (ECDC), Stockholm, Sweden

Citation style for this article:

Thomson G, Nicoll A. Responding to new severe diseases - the case for routine hospital surveillance and clinical networks in Europe . Euro Surveill. 2010;15(49):pii=19745. Available online: $\mathrm{http}: / /$ www.eurosurveillance.org/ViewArticle. aspx?Articleld=19745

Article published on 9 December 2010

Any review of the emergence of the more important infectious disease threats in the past few decades will note how many of them were first detected, or recognised as being serious, through unusual patterns of severely ill people appearing in hospitals (Table 1 ).

That was also the case for the 2009 influenza $A\left(\mathrm{H}_{1} \mathrm{~N}_{1}\right)$ pandemic: While the first detected cases were mild infections in children in the south-west of the United States, it was severe disease in Mexico City that led to the appreciation of the potential seriousness of the threat $[8,10]$. In this issue of Eurosurveillance a series of articles describes the initial surveillance in the European Union (EU) [11], how new comprehensive surveillance was developed in Iceland [12], the response in Italy [13], the form that detected mortality took in Germany [14] and clinical surveillance for severe cases in Denmark [15]. The Danish paper notably describes successful efforts to mount surveillance in intensive care units. It is striking that at a time when there was infection and disease in the community, it was the hospitals, and their paediatric services and intensive care units in particular, that were most under pressure [1618]. It is a truism that the severe cases are to be found in hospital. However, that is where some of the most important information on this pandemic was found, i.e. data and analyses that were needed to guide the countermeasures. A number of the analyses that filled in the gaps for ECDC's Known Unknowns (the important features that vary between pandemics and need to be known for control activities) eventually had to come from hospital sources [19]. It is therefore logical to make an effort to gather the early clinical, virological and epidemiological information during a pandemic from hospitals and clinicians in general and intensive care units in particular.

\section{TABLE 1}

Examples of important emerging infections detected through hospital observations since 1981

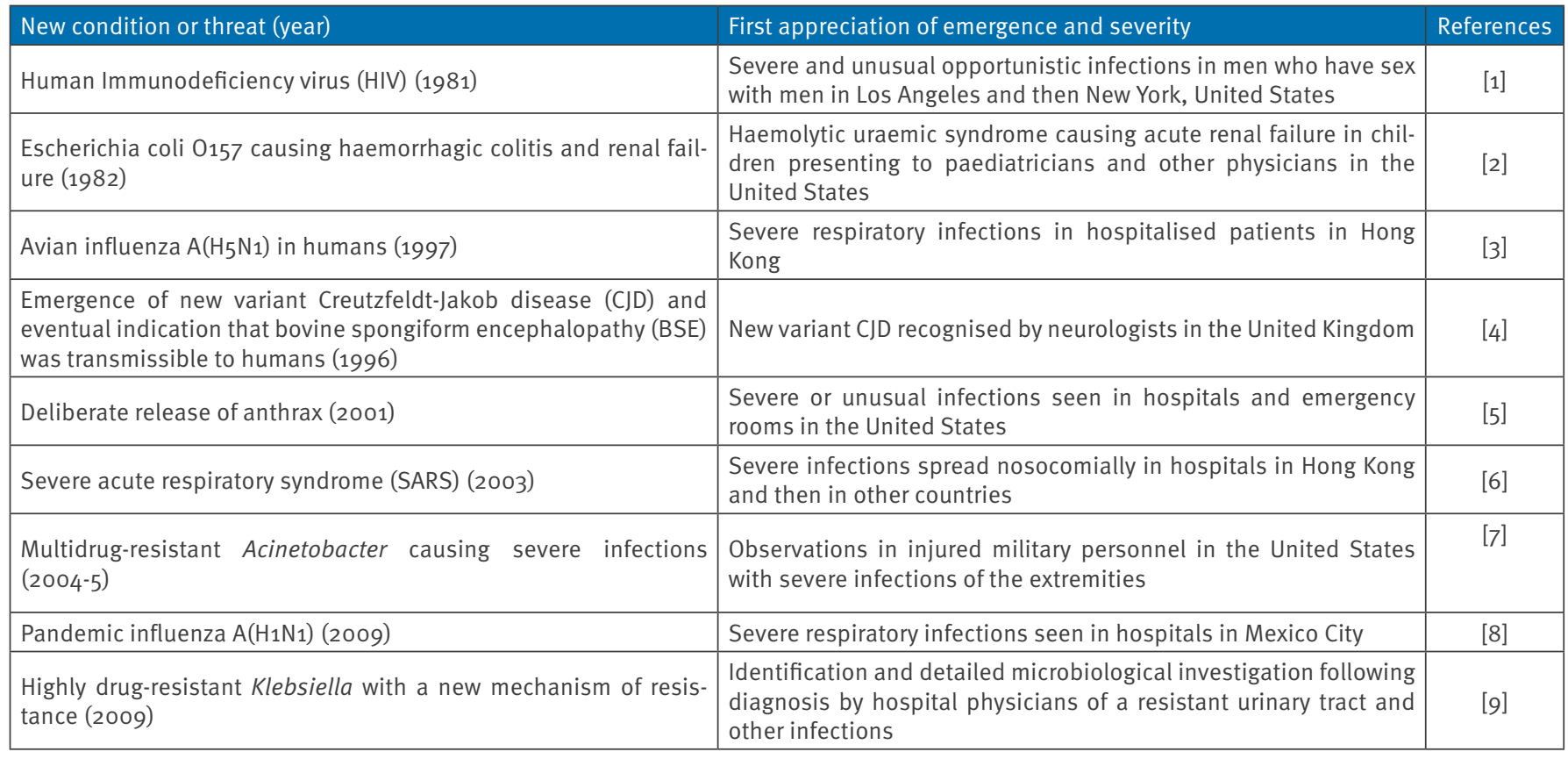


At the same time, hospital surveillance for severe acute respiratory infections (SARI) was one of the two most obvious weak links in the European strategy of surveillance in a pandemic [20] - the other weak link was delivering timely population-wide serological data and analyses [21]. These are not so much issues on a European level as weaknesses in the national systems. There are very few formal systems for hospital-based clinical surveillance in the EU. Neither ECDC nor the World Health Organization (WHO) can ask the Member States for additional analyses and data that they do not routinely collect. Collecting detailed clinical data in real time while clinicians are busy dealing with an outbreak remains a challenge. Even if the rapid collection of data is completed, e.g. via web-based tools, there also needs to be a rapid analysis fed back into the outbreak response.

These reasons alone make a strong case for establishing routine hospital-based clinical surveillance at least in sentinel settings and for linking clinical-microbiological services in international networks that collaborate with public health services and the authorities. However, there are other reasons why clinical networks should be there and function in emergencies (Table 2): The main aim should always be to improve patient care, to ensure that the care given is as safe as possible and that appropriate infection control measures are taken. The clinical lessons learned should ideally be captured in real time and linked with the microbiological and epidemiology results. Rapid analyses should be fed back into the response, providing for instance revised case definitions and improved clinical care [22].

These are not new observations. In 2003, the WHO rapidly set up a clinical network to respond to the epidemic of severe acute respiratory syndrome SARS [25]. It consisted of clinicians from as many as 10 countries discussing case management issues in real time, sharing experiences that were invaluable for the front line clinicians and ultimately improved patient care. Efforts were always made to have an epidemiologist and a virologist on the calls to ensure a more coherent and cross-disciplinary approach [25].

Of course there is a plethora of existing clinical networks and societies in Europe, including ones that deal with intensive care, clinical virology, respiratory disease and infections. However they are not usually structured to respond to emergencies, their links to the public health authorities tend to be unclear and they do not receive enduring official funds. It is also asking a lot of the voluntary officers that run these networks in their spare time to do more in a crisis when individual members are already stressed by an increased workload. However the example of the one international emergency clinical network set up during the 2009 influenza pandemic by the Health Protection Agency (HPA) in the United Kingdom (UK) is encouraging [25]. Similar networks were active or formed de novo in France (REVA-GRIPPE-SRLF), Spain and the Ukraine, and there are undoubtedly others [26].

Following the admission of the first severe cases of pandemic influenza $A\left(H_{1} N_{1}\right)$ into intensive care units in the UK, the HPA facilitated and coordinated discussions between intensive care clinicians from a wide range of fields, including specialists in intensive care, paediatrics, thoracic medicine, virology, epidemiology, and infectious diseases [22], including also the UK Department of Health and the WHO (Europe Regional Office and HQ Geneva). Disease experts and clinicians from outside of Europe were included from the beginning to ensure that the experiences made in Mexico and the rest of North America with 2009 pandemic influenza $A\left(\mathrm{H}_{1} \mathrm{~N}_{1}\right)$ and in the Far East with avian

TABLE 2

Potential purposes of clinical networks linked with public health in Europe

\begin{tabular}{|c|c|}
\hline Activity & Benefit \\
\hline $\begin{array}{l}\text { Empower clinicians at a local level, allowing for detection, early warning } \\
\text { and alerting of new threats }\end{array}$ & $\begin{array}{l}\text { Essential for the implementation of the International Health Regulations } \\
2005 \text { [23] }\end{array}$ \\
\hline $\begin{array}{l}\text { Share clinical experience and provide support to other teams for chal- } \\
\text { lenging clinical decisions }\end{array}$ & $\begin{array}{l}\text { Particularly important when dealing with a novel disease and limited in- } \\
\text { formation in the literature }\end{array}$ \\
\hline Respond rapidly with evidence-based clinical advice where possible & Evidence readily available to help with decision making \\
\hline $\begin{array}{l}\text { Collect clinical data in real time linked to laboratory and epidemiological } \\
\text { data }\end{array}$ & $\begin{array}{l}\text { Data analysed and fed back into the system promptly will help the clini- } \\
\text { cal response }\end{array}$ \\
\hline $\begin{array}{l}\text { Coordinate and contribute to the writing of guidance, in cooperation with } \\
\text { relevant stakeholders, notably professional societies }\end{array}$ & $\begin{array}{l}\text { In a novel disease scenario it is important to capture evidence of best } \\
\text { practice }\end{array}$ \\
\hline Agree on a platform to disseminate the guidance & Readily accessible guidance \\
\hline $\begin{array}{l}\text { Provide early warning from the first affected localities for other European } \\
\text { countries }\end{array}$ & $\begin{array}{l}\text { Countries have the opportunity to prepare for a new threat and to fulfil } \\
\text { the obligations of EU Decision } 2119 \text { to disseminate information that ben- } \\
\text { efits other European Countries European [24] }\end{array}$ \\
\hline $\begin{array}{l}\text { Provide training for clinicians in basic principles of outbreak response, } \\
\text { personal protective equipment, epidemiology, laboratory test limitations } \\
\text { and interpretation of result }\end{array}$ & $\begin{array}{l}\text { Continue to strengthen the clinical frontline, so that when the next novel } \\
\text { disease emerges it will be easier for them to manage }\end{array}$ \\
\hline $\begin{array}{l}\text { Assist the Global Outbreak Alert and Response Network (GOARN) and } \\
\text { European authorities such as the Humanitarian Aid department (ECHO) }\end{array}$ & $\begin{array}{l}\text { Opportunity to support other countries and foster international relations; } \\
\text { experience gained abroad could be fed back into national plans }\end{array}$ \\
\hline
\end{tabular}


influenza $A\left(\mathrm{H}_{5} \mathrm{~N}_{1}\right)$ did not have to be relearnt. They followed a format similar to the traditional clinical 'Grand Round' with treating clinicians seeking peer review of their proposed clinical management programmes. The Practice Notes for the care of critically ill adults and children were disseminated via the websites of relevant societies and the HPA $[27,28]$. Dedicated teleconferences examined particular elements of care including infection control in intensive care, paediatric care, and pregnancy. This was a demanding process requiring the time and efforts by clinicians and experts in many countries as well as the HPA itself.

It is striking how well the initial impressions from these networks held up to the evidence that eventually appeared in the peer-reviewed literature, for example the early observations regarding differences to seasonal influenza (children being relatively overrepresented and older people underrepresented), special challenges in managing the profound hypoxaemia, groups at higher risk of severe disease (the very obese, pregnant women, asthma patients, certain ethnic groups), and the benefit of higher than normal doses of oseltamivir [22].

Particularly valuable for the early risk assessments was to combine the hospital experience with that in the community. It was apparent early on that severe as the cases seen in hospital were, they were uncommon compared to the many infections known to have occurred in places with good surveillance affected early (New York and parts of the UK)[21]. This allowed ECDC to be cautiously optimistic in its risk assessments in early 2009 [29].

The first HPA teleconference call took place in early June and the first practice note that the UK clinicians could look to for guidance was published in August on the professional websites $[27,28]$. However the formal dissemination of much of that information was a problem. Publication of most clinical observations proceeds slowly and those with the information did not always appreciate the obligation to disseminate their core messages through rapid systems like the Early Warning and Response System (for Europe) and the International Health Regulations alerting system (global). In a novel situation there will be a lag time as information is collected prior to wider dissemination.

A number of lessons can be learnt from the experience with the 2009 pandemic. Firstly, there is a need for routine surveillance of severe infections in hospitals. This could be in sentinel hospitals or for some conditions at a population level (in the United States all childhood deaths associated with influenza are notifiable to the Centers for Disease Control and Prevention) $[30,31]$. Secondly, the surveillance activities should be overseen by interdisciplinary groups of clinicians and microbiologists as well as public health institutes. Thirdly, the specifications for hospital information systems should facilitate this kind of work. And fourthly, when emergencies arise, these surveillance systems should be reinforced with people and resources. These lessons need to be acted upon now as there are indications in Europe of disinvestment in the surveillance systems established during the pandemic at a time when early information on severe cases remains of high importance in Europe [32]. Table 2 highlights the benefits of operational clinical networks. Ideally a framework should be built prior to an outbreak, bringing together the multi-disciplinary groups for training and preparedness. The network would be activated by agreed triggers and contain a core group to facilitate its functions and outputs.

\section{References}

1. Centers for Disease Control. Pneumocystis Pneumonia - LoS Angeles MMWR Morb Mortal Wkly Rep. 1981;30:250-2.

2. Riley L, Remis R, Helgerson S, McGee H, Wells J, Davis B, et al. (Hemorrhagic colitis associated with a rare Escherichia coli serotype. N Engl J Med 1983;308(12):681-5.

3. Mounts AW, Kwong H, Izurieta HS, Ho Y, Au T, Lee M, et al. Case-control study of risk factors for avian influenza $A\left(\mathrm{H}_{5} \mathrm{~N}_{1}\right)$ disease, Hong Kong, 1997. J Infect Dis. 1999;180(2):505-8.

4. Will RG, Ironside JW, Zeidler M, Cousens SN, Estibeiro K, Alperovitch A, et al. A new variant of Creutzfeldt-Jakob disease in the UK. Lancet. 1996;347(9006):921-5.

5. Jernigan JA, Stephens DS, Ashford DA, Omenaca C, Topiel MS, Galbraith $M$, et al. Bioterrorism-related inhalational anthrax: the first 10 cases reported in the United States. Emerg Infect Dis. 2001;7(6):933-44.

6. Heymann DL, Rodier G. Global surveillance, national surveillance, and SARS. Emerg Infect Dis. 2004;10(2):173-5;

7. Davis KA, Moran KA, McAllister CK, Gray PJ. Multidrugresistant Acinetobacter extremity infections in soldiers. Emerg Infect Dis. 2005;11(8):1218-24.

8. Centers for Disease Control and Prevention (CDC). Update: Novel Influenza A ( $\left.\mathrm{H}_{1} \mathrm{~N}_{1}\right)$ Virus Infection - Mexico, March-May, 2009. MMWR Morb Mortal Wkly Rep. 2009;58(21);585-9.

9. Yong D, Toleman MA, Giske CG. Characterization of a new metallo- $\beta$-lactamase gene, blaNDM-1, and a novel erythromycin esterase gene carried on a unique genetic structure in Klebsiella pneumoniae sequence type $14 \mathrm{from}$ India. Antimicrob Agents Chemother. 2009;53(12):5046-54.

10. Centers for Disease Control and Prevention (CDC) 2009. Swine influenza $A\left(\mathrm{H}_{1} \mathrm{~N}_{1}\right)$ infection in two children--Southern California, March-April 2009. MMWR Morb Mortal Wkly Rep. 2009;58(15):400-2

11. Devaux I, Kreidl P, Penttinen P, Salminen M, Zucs P, Ammon A, et al. Initial surveillance of 2009 influenza $A\left(\mathrm{H}_{1} \mathrm{~N}_{1}\right)$ pandemic in the European Union and European Economic Area, April - September 2009. Euro Surveill. 2010;15(49): pii=19740. Available online: http://www.eurosurveillance.org/ViewArticle. aspx?Articleld $=19740$

12. Sigmundsdottir G, Gudnason T, Ólafsson Ö, Baldvinsdóttir GE, Atladottir A, Löve A, et al. Surveillance of influenza in Iceland during the 2009 pandemic. Euro Surveill. 2010;15(49):pii=19742. Available online: http://www. eurosurveillance.org/ViewArticle.aspx?Articleld =19742

13. Rizzo C, Rota MC, Bella A, Giannitelli S, De Santis S, Nacca $\mathrm{G}$, et al. Response to the 2009 influenza $A\left(\mathrm{H}_{1} \mathrm{~N}_{1}\right)$ pandemic in Italy. Euro Surveill. 2010;15(49):pii=19744. Available online: http://www.eurosurveillance.org/ViewArticle. aspx?Articleld $=19744$

14. Wilking $\mathrm{H}$, Buda $\mathrm{S}$, von der Lippe $\mathrm{E}$, Altmann D, Krause $\mathrm{G}$, Eckmanns T, et al. Mortality of 2009 pandemic influenza $\mathrm{A}\left(\mathrm{H}_{1} \mathrm{~N}_{1}\right)$ in Germany. Euro Surveill. 2010;15(49):pii=19741. Available online: http://www.eurosurveillance.org/ViewArticle. aspx?Articleld $=19741$

15. Gubbels S, Perner A, Valentiner-Branth P, Mølbak K. National surveillance of pandemic influenza $A\left(\mathrm{H}_{1} \mathrm{~N}_{1}\right)$ infection-related admissions to intensive care units during the 2009-10 winter peak in Denmark: two complementary approaches. Euro Surveill. 2010;15(49):pii=19743. Available online: http://www. eurosurveillance.org 
16. European Centre for Disease Prevention and Control. The $2009 \mathrm{~A}\left(\mathrm{H}_{1} \mathrm{~N}_{1}\right)$ pandemic in Europe. Stockholm: ECDC; 2010. Available from: http://www.ecdc.europa.eu/en/publications/ Publications/101108_SPR_pandemic_experience.pdf

17. Widgren K, Nielsen J, Mølbak K. Registry-based surveillance of influenza-associated hospitalisations during the 2009 influenza pandemic in Denmark: the hidden burden on the young. PLoS One. 2010;5(11):e13939. doi:10.1371/journal. pone.0013939.

18. Writing Committee of the WHO Consultation on Clinical Aspects of Pandemic $\left(\mathrm{H}_{1} \mathrm{~N}_{1}\right) 2009$ Influenza, Bautista $\mathrm{E}$, Chotpitayasunondh T, Gao Z, Harper SA, Shaw M, et al. Clinical aspects of pandemic 2009 influenza $A\left(\mathrm{H}_{1} \mathrm{~N}_{1}\right)$ virus infection. $\mathrm{N}$ Engl J Med. 2010;362(18):1708-19.

19. Nicoll A, Ammon A, Amato Gauci A, Ciancio B, Zucs P, Devaux I, et al. Experience and lessons from surveillance and studies of the 2009 pandemic in Europe. Public Health. 2010;124(1):14-23.

20. European Centre for Disease Prevention and Control. Overview of surveillance of influenza 2009/2010 in the EU/EEA. Stockholm: ECDC; Sept 2009. Available from: http://www.ecdc. europa.eu/en/publications/Publications/o909_TED_Overview of_Surveillance_of_Influenza_2009-2010_in_EU-EEA.pdf

21. Seroepidemiological studies of pandemic influenza $A\left(\mathrm{H}_{1} \mathrm{~N}_{1}\right)$ 2009 virus. Wkly Epidemiol Rec. 2010;85(24):229-35.

22. Walunj A, Thomson G, Gent N, Dunning J, Brett S. Global clinical networking and pandemic influenza. J Int Care Soc. 2010;11(3):165-70.

23. Fifty-eighth World Health Assembly, Resolution WHA58.3: revision of the International Health Regulations. Geneva: World Health Organisation; 2005. Available from: http://www.who. int/gb/ebwha/pdf_files/WHA58/WHA58_3-en.pdf

24. Council Decision No 2119/98/EC of the European Parliament and of the Council of 24 September 1998 setting up a network for the epidemiological surveillance and control of communicable diseases in the Community. Official Journal of the European Communities 3. 10. $98 \mathrm{~L}$ 268. Available from: http://eur-lex.europa.eu/pri/en/oj/dat/1998/__268/ I_26819981003enoo010006.pdf

25. Mackenzie JS, Drury P, Ellis A, Grein T, Leitmeyer KC, Mardel $S$, et al. The WHO Response to SARS and Preparations for the Future. In: Knobler S, Mahmoud A, Lemon S, Mack A, Sivitz L, Oberholtzer K, editors. Learning from SARS. Preparing for the Next Disease Outbreak - Workshop summary. Washington, D.C: The National Academies Press; 2004. p 42 -50.

26. Brun-Buisson C, Richard J-C M, Mercat A, Brochard L for the REVA-GRIPPE-SRLF Registry. Corticosteroid therapy in early ARDS secondary to influenza $A\left(\mathrm{H}_{1} \mathrm{~N}_{1}\right)$ (2009) pneumonia: data from the REVA-self registry. E-Poster ESICM Congress; 2010 October 9-13; Barcelona. Available from: http:// poster-consultation.esicm.org/ModuleConsultationPoster/ posterDetail.aspx?intldPoster $=1162$

27. Pandemic $\mathrm{H}_{1} \mathrm{~N}_{1} 2009$ Clinical Practice Note - Managing critically ill cases. London: Health protection Agency; 2009 August 11. Available from: http://www.hpa.org.uk/web/ HPAwebFile/HPAweb_C/1248854036293

28. Paediatric practice note for the management of critically ill children with pandemic $\left(\mathrm{H}_{1} \mathrm{~N}_{1}\right) 2009$ Influenza. London: Health protection Agency; 2009 October 24. Available from: http:// www.hpa.org.uk/web/HPAwebFile/HPAweb_C/1254510681244

29. Jakab Z. ECDC Director's hearing with the European Parliament's ENVI Committee. European Parliament, Brussels 2009 September 1. Available from: http://ecdc.europa.eu/ en/aboutus/organisation/Founding $\% 20$ Director $\% 20 \% 20$ Speeches/0909_DS_Brussels.pdf

30. Reed C, Angulo FJ, Swerdlow DL, Lipsitch M, Meltzer MI, Jernigan D, et al. Estimates of the prevalence of pandemic (H1N1) 2009, United States, April-July 2009. Emerg Infect Dis. 2009;15(12):2004-7.

31. Cox CM, Finelli L. Blanton L, Dhara R, Brammer L. 2009 pandemic influenza $A\left(\mathrm{H}_{1} \mathrm{~N}_{1}\right)$ deaths among children - United States, 2009-2010. Clin. Infect. Dis. Forthcoming

32. Nicoll A, Sprenger M. The end of the pandemic - what will be the pattern of influenza in the 2010-11 European winter and beyond? . Euro Surveill. 2010;15(32):pii=19637. Available from: http://www.eurosurveillance.org/ViewArticle. aspx?Articleld $=19637$ 